\title{
СОСТОЯНИЕ ГУМУСА В НЕКОТОРЫХ ТИПАХ ЗАЛЕЖНЫХ ПОЧВ ПРИМОРЬЯ
}

\author{
Л. Н. Пуртова, И. В. Киселева, М. Л. Бурдуковский \\ ФГБУН «Федеральный научный иентр биоразнообразия наземной биоты Восточной Азии» \\ ДВО РАН, г. Владивосток \\ E-mail: Purtova@biosoil.ru; Kiseleva-iv@inbox.ru; burmaxs@inbox.ru
}

\begin{abstract}
Выполнена оценка показателей гумусного состояния залежных темногумусовых подбелов и аллювиальных серогумусовых почв Приморья. В залежных аллювиальных серогумусовых почвах преобладала гуматная направленность в процессе гумусообразования, тогда как в темногумусовых подбелах она изменялась на гуматно-фульватную. Исследуемым типам почв свойственна высокая степень гумификации органического вещества. При нахождении почв в залежи отмечено сокращение доли гуминовых кислот, связанных с $\mathrm{Ca}^{2+}$, по сравнению с их пахотными аналогами. Рассчитаны пулы лабильного и стабильного углерода. Основная доля углерода (от 67 до 73\%) в исследуемых почвах содержится в стабильном пуле. Снижение соотношения между содержанием углерода лабильного и стабильного пулов в исследуемых почвах залежей свидетельствовало об увеличении доли углерода стабильного пула и переходе гумуса в более устойчивое состояние.
\end{abstract}

Ключевые слова: почвы, залежь, гумусное состояние, пулы углерода, каталазная активность.

DOI: $10.34078 / 1814-0998-2019-2-46-54$

В Приморском крае начиная с 2013 г. реализуется Государственная программа развития сельского хозяйства, одним из пунктов которой является «Ввод в оборот неиспользуемой пашни и залежных земель сельскохозяйственного назначения» (2012). Возвращение земель из залежи в пашню не всегда рентабельно. При распашке залежных земель нередко наблюдаются негативные процессы, проявляющиеся в резкой активизации разложения органического вещества, что ведет к существенному снижению уровня плодородия почв (Платонычева и др., 2013). В связи с этим весьма актуально проведение исследований по оценке содержания органического вещества, которое является не только источником минерального питания, но и регулятором физико-химических свойств почв, а также дает представление о том, на каком этапе зарастания залежи целесообразно проводить ее распашку (Полякова и др., 2014).

Прекращение обработки почвы и постагрогенная смена растительности приводят к изменениям как запасов углерода, так и состава орга-

(C) Пуртова Л. Н., Киселева И. В., Бурдуковский М. Л., 2019 нического вещества в целом (Литвинович, Павлова, 2010; Чалая, 2012). Многие исследователи гумусного состояния различных типов почв, находящихся в залежи, подтверждают, что по мере увеличения срока снятия антропогенной нагрузки статус гумусированности почв повышается (Poulton et al., 2003; Zhang Bin, Penc XinHua, 2006; Романовская, Аракелян, 2007; Wright et al., 2007). Средняя скорость накопления углерода в залежных почвах России в течение первых 20 лет после вывода из сельскохозяйственного использования составляет $105 \pm 10$ г С/M ${ }^{2}$ в год (Kurganova et al., 2014).

При выведении из сельскохозяйственного оборота почв с искусственно созданным высоким, не характерным для почв данного генезиса содержанием органического вещества отмечалось явное уменьшение содержания гумуса и его запасов (Литвинович, Павлова, 2007).

Темногумусовые подбелы и аллювиальные серогумусовые почвы (Классификация..., 2004) имеют высокий балл бонитета и относятся к одним из лучших по показателю плодородия почвам. По своему местоположению, физико-химическим, агрономическим свойствам и наиболее перспективным направлениям использования в 
зависимости от морфолого-генетических особенностей темногумусовые подбелы отнесены к третьей группе. Почвы формируются в пределах озерных террас, в нижней части пологих склонов на легко-, среднесуглинистых и глинистых отложениях и образуют основной фонд агрономически ценной пашни (34.5\%). Аллювиальные серогумусовые почвы под пашенными угодьями в Приморском крае составляют до 15.6\%. Почвы занимают низкие в геоморфологическом отношении уровни, хорошо дренированы, в основном среднегумусированы (Костенков, Ознобихин, 2006). В связи с сокращением пахотных площадей большинство почв, используемых в земледелии края, были переведены в залежь.

Исследований по определению состояния гумуса в залежных темногумусовых подбелах и аллювиальных серогумусовых почвах Приморья, с учетом складывающихся пулов углерода, ранее не проводилось.

Существует несколько подходов в исследовании пулов углерода. Б. М. Когут с соавторами (2016) рассмотрел вклад структурно-агрегатных отдельностей в общие запасы $\mathrm{C}_{\text {орг. }}$ в гумусовом горизонте дерново-подзолистых почв и установил наличие достоверных связей между содержанием общего $\mathrm{C}_{\text {орг. }}$, лабильного $\left(\mathrm{C}_{\text {лаб. }}\right)$ и активного $\left(\mathrm{C}_{\mathrm{o}}\right)$ органического вещества. Он предложил концептуальную схему подразделения почвенного органического вещества на активный, медленный (промежуточный) и пассивный пулы. Пулы углерода расчитывали с учетом содержания $\mathrm{C}_{\text {орг. }}$ в условиях бессменного парования без поступления свежего растительного материала, но с регулярными обработками.

Между тем отсутствие данных по содержанию $\mathrm{C}_{\text {орг. }}$ в почвах бессменного пара, но с регулярными обработками не позволило применить данную схему в наших исследованиях.

С. Ю. Зорина с соавторами (2014) предложили другой подход в изучении пулов органического углерода, основанный на использовании данных анализа фракционно-группового состава гумуса по методу Пономаревой - Плотниковой, который обеспечивает выделение не только качественно различных по природе гуминовых (ГК), фульвокислот (ФК) и гумина, но и фракций ГК и ФК, отличающихся по характеру их связи с минеральными компонентами. Несмотря на некоторую условность, данный подход позволяет выделить лабильный и стабильный пулы углерода в гумусе почв. Показатель трансформации системы гумусовых веществ, основанный на соотношении подвижных и малоподвижных фракций, позволяет оценить особенности формирования пулов углерода - лабильного (П $)$ и стабильного
$\left(\mathrm{M}_{\text {пा }}\right)$. Показатель П г демонстрирует способность гумуса к минерализации, что приводит к дестабилизации системы, а $\mathrm{M}_{\text {пг }}$ - глубину гумификации, обеспечивающую ее стабильность. Соотношение лабильного и стабильного пулов углерода разрешает выявить направленность трансформации гумусного состояния почв.

Цель данной работы - выявление направленности трансформации гумусного состояния залежных почв с учетом соотношения пулов углерода.

В задачи исследований входило:

1) провести оценку гумусного состояния почв;

2) исследовать соотношение лабильного и стабильного пулов углерода в залежных почвах.

\section{ОБЪЕКТЫ И МЕТОДЫ ИССЛЕДОВАНИЙ}

Исследования проводили на бывших пахотных землях Уссурийского городского округа Приморского края (рис. 1), объект - залежные темногумусовые подбелы и аллювиальные серогумусовые почвы.

Темногумусовый подбел сформирован под вейниково-злаковыми лугами с набором генетических горизонтов: AU (0-10 см) - темно-серый, легкосуглинистый, крупнозернистой структуры, задернован, постепенно переходящий в более плотный горизонт Elnng (10-30 см) - коричневосерый, легкосуглинистый, плотный, с большим количеством железо-марганцевых конкреций (далее - конкреции), с заметным переходом в BELg (30-40 см) - серый, плотный, среднесуглинистый, встречаются конкреции, глыбистокомковатый с постепенным переходом в горизонт BTg (40-70 см) - плотный, серо-бурого цвета, глинистый и горизонт Сg (70-90 см) - представляет собой плотную глину.

Темногумусовый подбел глееватый сформирован в условиях постоянного или длительного переувлажнения под осоково-злаковым лугом. Профиль почвы имеет следующий набор генетических горизонтов: AU (0-12 см) - темно-серый, рыхлый, зернистой структуры, сильно задернован, постепенно переходящий в горизонт Elnng (12-22 см) - светло-серый, встречаются конкреции, супесчаный, с резким переходом в ВТg (22-55 см) - серо-коричневый, свежий, плотный, легкосуглинистый, комковато-глыбистый, постепенно переходит в горизонт $\mathrm{Cg}(55-90$ см) сизовато-серый, плотный, среднесуглинистый, комковатой структуры.

Аллювиальная серогумусовая почва расположена на первой террасе р. Раздольная под вейниково-осоковой растительностью. Профиль состоит из горизонтов: AY (0-20 см) -бурый, рых- 


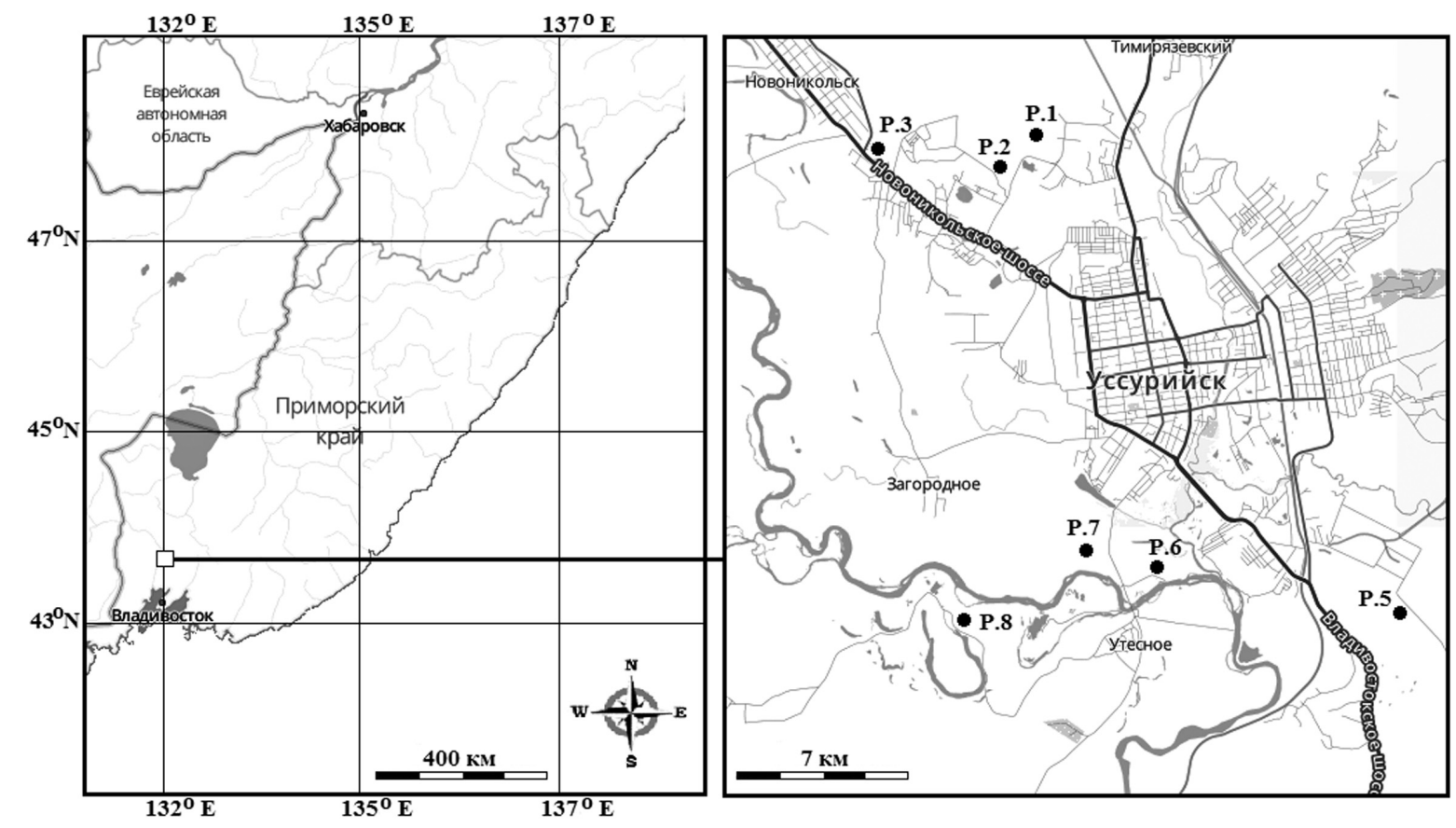

Рuc. 1. Карта-схема района исследований

Fig. 1. Map of the research area

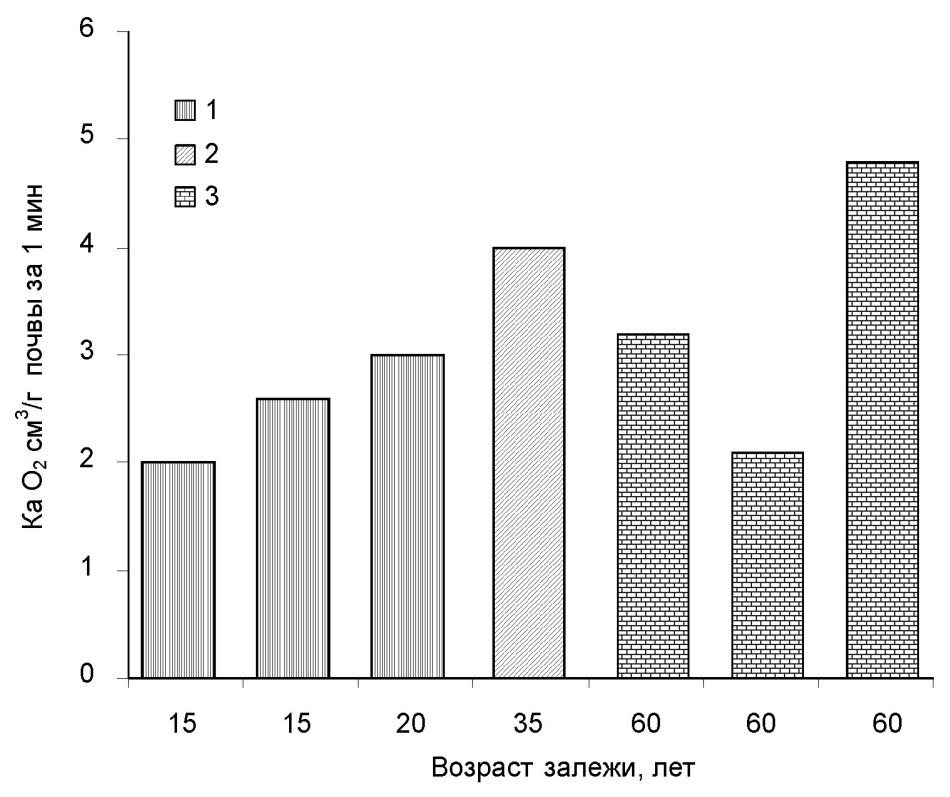

Puc. 2. Показатели каталазной активности в залежных почвах Приморья: 1 - темногумусовый подбел; 2 - темногумусовый подбел глееватый; 3 - аллювиальная серогумусовая почва

Fig. 2. Indicators of catalase activity in fallow soils of Primorye: 1 - dark-humus bleached horizon; 2 - dark-humus gleyic bleached horizon; 3 - alluvial gray-humus soil

лый, супесчаный с обильным включением корней растений, с постепенным переходом в I (2050 см) - коричнево-бурый, легкосуглинистый, уплотненный. Далее следует горизонт II (5070 см) - без изменения цвета, плотный с большим количеством мелких конкреций, с постепенным переходом в $\mathrm{Cg}(70-110$ см) - коричнево-бурый с ржавыми пятнами, плотный, тяжелосуглинистый.

Изучаемые почвы пребывали в залежном состоянии 15, 20 лет (темногумусовый подбел), 35 (темногумусовый подбел глееватый) и более 60 лет (аллювиальные серогумусовые). Исследования проведены в поверхностных гумусово-аккумулятивных горизонтах, в которых наиболее активно протекают процессы трансформация органического вещества микрофлорой.

При определении содержания гумуса, использован метод Тюрина, его фракционно-группового состава-метод Пономаревой - Плотниковой (Орлов, Гришина 1981). Величину лабильного и стабильного пулов определяли по содержанию углерода в отдельных фракциях гумусовых веществ: лабильного пула углерода в гумусе почв $\left(\mathrm{C}_{\text {пг }}=\Gamma К 1+\right.$ ФК1 $\mathrm{a}+\Phi К 1)$, стабильного $-\left(\mathrm{C}_{\mathrm{M}}^{\mathrm{nI}}=\right.$ ГК $2+$ ГК 3 + ФК2 + ФК3 + ГМ) (Зорина и др., 2014). Оценка гумусного состояния почв дана по градациям Д. С. Орлова с соавторами (2004). В работе рассмотрен не весь спектр показателей, а наиболее информативные, отражающие генетические различия гумуса и формы связи с минеральной частью почв. Запасы гумуса рассчитаны по формуле: $\Gamma \times \mathrm{H} \times \mathrm{d}$, где $\Gamma$ - содержание гумуса, \%; $\mathrm{H}$ - мощность исследуемого горизонта, см; d - плотность сложения 


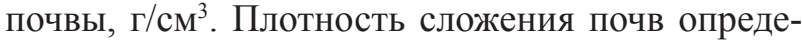
лена объемно-весовым методом (Агрофизические..., 1966).

Ферментативную (каталазную) активность почв исследовали газометрическим методом. Каталазную активность оценивали по шкале Д. Г. Звягинцева (Методы..., 1991).

\section{РЕЗУЛЬТАТЫ И ОБСУЖДЕНИЕ}

Формирование залежных почв происходит в условиях резко континентального с муссонными чертами климата (Витвицкий, 1969). Неравномерное выпадение осадков в течение года нередко вызывает их переувлажнение. Почвы расположены в пределах речных террас на легко-, среднесуглинистых и глинистых отложениях.
Нахождение почв в залежном состоянии привело к изменению их аккумулятивной толщи, что зафиксировано в общих морфологических признаках. В темногумусовых подбелах, находящихся в залежи более 20 лет, отмечено разделение исходного пахотного горизонта (0-20 cм) на подгоризонты $(0-10,10-20,0-12,12-20$ см). По мощности горизонта $\mathrm{AU}$ темногумусовые подбелы отнесены к маломощным (10 см) - возраст залежи 15 лет и слабо-, среднемощным - 20-летняя залежь. Темногумусовые подбелы глееватые отнесены к слабо-, среднемощным (12 см). Мощность горизонта AY в аллювиальной серогумусовой почве соответствовала среднетипичным показателям пахотного горизонта (20 см).

Прослеживались различия и в содержании органического вещества. Как показали результа-

Таблииа 1. Некоторые показатели гумусного состояния залежных почв Приморья

Table 1. Some indicators of humus status in Primorye's fallow soils in

\begin{tabular}{|c|c|c|c|c|c|c|c|c|}
\hline \multirow{2}{*}{$\begin{array}{c}\text { Разрез } \\
\text { (возраст } \\
\text { залежи) }\end{array}$} & \multirow{2}{*}{ Почва } & \multirow{2}{*}{ Гумус,\% } & \multirow{2}{*}{$\begin{array}{c}\text { Запасы } \\
\text { гумуса } \\
\text { в слое } \\
0-20 \text { см, }\end{array}$} & \multicolumn{3}{|c|}{$\begin{array}{c}\text { Доля фракции гуминовых } \\
\text { кислот, в \% от их суммы }\end{array}$} & \multirow{2}{*}{$\mathrm{C}_{\mathrm{r \textrm {K }}} / \mathrm{C}_{\mathrm{\phi K}}$} & \multirow{2}{*}{$\begin{array}{c}\text { Степень } \\
\text { гумифи- } \\
\text { кации }\end{array}$} \\
\hline & & & & $1^{*}$ & $2 * *$ & $3 * * *$ & & \\
\hline \multicolumn{9}{|c|}{ Залежные почвы } \\
\hline $\begin{array}{c}\text { Р. } 1 \\
\text { (35 лет) }\end{array}$ & $\begin{array}{c}\text { Темногумусовый } \\
\text { подбел глееватый }\end{array}$ & 8.74 & 102.9 & 56.2 & 12.2 & 31.6 & 0.97 & 32.8 \\
\hline $\begin{array}{c}\text { Р. } 2 \\
\text { (15 лет) }\end{array}$ & Темногумусовый подбел & 3.25 & 61.6 & 36.5 & 33.2 & 30.3 & 0.92 & 30.4 \\
\hline $\begin{array}{c}\text { Р. } 3 \\
(15 \text { лет) }\end{array}$ & То же & 3.46 & 62.5 & 31.7 & 31.7 & 36.6 & 0.97 & 32.8 \\
\hline $\begin{array}{c}\text { Р. } 5 \\
\text { (20 лет) }\end{array}$ & $-"-$ & 5.53 & 122.4 & 34.1 & 33.2 & 32.7 & 1.35 & 38.2 \\
\hline $\begin{array}{c}\text { Р. } 6 \\
(60 \text { лет) }\end{array}$ & $\begin{array}{l}\text { Аллювиальная } \\
\text { серогумусовая }\end{array}$ & 5.05 & 76.7 & 37.7 & 37.7 & 24.6 & 1.49 & 38.1 \\
\hline $\begin{array}{c}\text { Р. } 7 \\
(60 \text { лет) }\end{array}$ & То же & 3.83 & 49.2 & 31.6 & 45.5 & 22.9 & 1.63 & 42.9 \\
\hline $\begin{array}{c}\text { Р. } 8 \\
\text { (60 лет) }\end{array}$ & $-"-$ & 5.00 & 68.3 & 41.3 & 27.8 & 30.9 & 1.10 & 31.5 \\
\hline \multicolumn{9}{|c|}{ Целинные и пахотные почвы } \\
\hline 1 & $\begin{array}{c}\text { Агротемногумусовый } \\
\text { подбел глееватый }\end{array}$ & 3.62 & 94 & 18.5 & 53.0 & 28.5 & 1.0 & 25.5 \\
\hline $2 * * * *$ & $\begin{array}{c}\text { Темногумусовый подбел } \\
\text { (целина) }\end{array}$ & 3.63 & - & 32.6 & 46.0 & 18.0 & 1.05 & - \\
\hline 3 & $\begin{array}{c}\text { Агротемногумусовый } \\
\text { подбел }\end{array}$ & 3.40 & 120.0 & 5.7 & 50.0 & 42.0 & 0.80 & 26.9 \\
\hline $4 * * * *$ & То же & 3.55 & 115.0 & 24.3 & 64.3 & 11.3 & 1.74 & 34.5 \\
\hline $5 * * * *$ & $\begin{array}{l}\text { Агрогумусовая } \\
\text { аллювиальная }\end{array}$ & 2.70 & 63.2 & 23.9 & 62.5 & 13.5 & 1.34 & 28.7 \\
\hline
\end{tabular}

*Доля 1-й фракции гуминовых кислот, «свободных» и связанных с полуторными оксидами.

** Доля 2-й фракции гуминовых кислот, связанных с $\mathrm{Ca}^{2+}$.

*** Доля 3-й фракции гуминовых кислот, прочно связанных с минеральной основой почв.

**** Названия почв приведены согласно классификации 2004 г. В оригинальной работе темногумусовому подбелу соответствует лугово-бурая оподзоленная почва, агрогумусовой аллювиальной - остаточнопойменная пахотная почва. Прочерк - нет данных. 
ты исследований, содержание гумуса в исследуемых залежных почвах варьирует от низких до высоких значений (табл. 1). В залежных темногумусовых подбелах и аллювиальных серогумусовых почвах содержание гумуса находится на уровне «низких» и «ниже средних» (от 3.25 до $5.53 \%$ ), а в темногумусовых подбелах глееватых - высоких показателей (8.74\%).

Увеличение содержания органического углерода в поверхностном горизонте залежных темногумусовых подбелов глееватых во многом связано со значительным привносом органического вещества с корневой массой растений. Этому во многом способствовало их расположение под осоково-злаковой растительностью, что привело к формированию горизонта $\mathrm{AU}$, густо пронизанного переплетенными живыми и отмершими корнями растений.

Согласно литературным данным (Синельников, 2000; Хавкина, 2004; Ковалева и др., 2016; Пуртова и др., 2017), в пахотных темногумусовых подбелах Уссурийского городского округа содержание гумуса варьирует в среднем от 3.3 до $4.3 \%$. Исходя из этого, при оставлении изученных почв в залежи на срок менее 15 лет содержание гумуса в них отмечается на уровне фонового. В более зрелых залежах можно наблюдать увеличение содержания гумуса и его запасов. Это объясняется прежде всего прекращением выноса органического материала с урожаем и накоплением его в пределах почвенного профиля.

Запасы гумуса в 20-сантиметровом слое залежных подбелов темногумусовых изменялись от низких до средних. При нахождении в залежи более 20 лет запасы гумуса в них соответствовали уровню их пахотных аналогов (см. табл. 1). В то же время по сравнению с аллювиальными серогумусовыми почвами, находящимися в залежи около 60 лет, запасы гумуса были выше. В данном случае это связано с более высокими показателями плотности сложения горизонта Elnng темногумусовых отбеленных почв

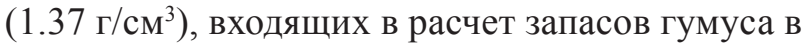
слое 0-20 см. В аллювиальных серогумусовых почвах плотность сложения в горизонте AY co-

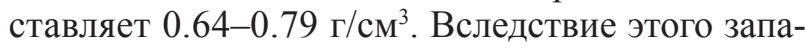
сы гумуса колебались от очень низких до низких значений.

С увеличением времени нахождения подбелов темногумусовых в залежном состоянии отмечена тенденция к возрастанию показателей степени гумификации органического вещества. В более зрелых подбелах темногумусовых глееватых (35 лет) степень гумификации оказывается ниже. На наш взгляд, это связано со складывающимся менее благоприятным водно-воздушным режи- мом. Подбелы темногумусовые глееватые испытывают поверхностное переувлажнение, вследствие чего процессы трансформации органического вещества несколько затормаживаются. Это в свою очередь ведет к накоплению органического вещества, снижению параметров плотности сложения почв и, в конечном итоге, к сравнительно меньшим запасам гумуса.

В групповом составе гумуса преобладали устойчивые фракции гуматов и фульватов. Во фракционном составе гумуса доминировали гуминовые кислоты, связанные с устойчивыми полуторными оксидами и глинистыми минералами, доля которых в исследуемых почвах залежей достигала высоких значений. Количество гуминовых кислот, «свободных» и связанных с $\mathrm{Ca}^{2+}$, было низким (см. табл. 1). Наиболее низкое содержание ГК 2-й фракции отмечено для темногумусовых глееватых подбелов, испытывающих периодическое переувлажнение. Для них характерно увеличение фульвокислот в составе гумуca, что хорошо прослеживается по сужению показателя соотношения $\mathrm{C}_{\text {гк }} / \mathrm{C}_{\text {фк }}$ по сравнению с темногумусовыми подбелами. В пахотных почвах Уссурийского района доля ГК, связанных с $\mathrm{Ca}^{2+}$, достигает $60 \%$ от суммы ГК, что соответствует уровню высоких значений (Синельников, 2000; Хавкина, 2004). Снижение доли 2-й фракции в почвах залежей в первую очередь обусловлено прекращением внесения органических и минеральных удобрений.

Тип гумуса в темногумусовых подбелах и глееватых варьировал от гуматно-фульватного (р. 1, $2,3)$ до фульватно-гуматного (р. 5). В аллювиальных серогумусовых почвах залежей в составе гумуса среди его основных компонентов явно доминировали гуминовые кислоты, а тип гумуса изменялся от фульватно-гуматного (p. 6,8$)$ до гуматного (р. 7). Подобные различия явно свидетельствовали о разной направленности процессов трансформации органического вещества в темногумусовых подбелах и аллювиальных серогумусовых почвах залежей. Более полную картину изменений в направленности процессов трансформации гумусного состояния почв дают сведения о лабильном и устойчивом к минерализации пуле почвенного органического вещества (Ларионова и др., 2011; Зорина и др., 2014). Как показали результаты проведенных исследований, основная доля углерода в гумусе залежных почв содержится в стабильном пуле (табл. 2).

Это характеризует сравнительно устойчивое состояние гумусовой системы почв. В темногумусовых подбелах глееватых содержание углерода лабильного пула повышается до 1603.7 мг/100 г почвы, что связано с по- 
Таблица 2. Величина пулов углерода в гумусе залежных почв Приморья

Table 2. Sizes of carbon pools in the humus of Primorye's fallow soils of

\begin{tabular}{|c|c|c|c|c|c|}
\hline \multirow{2}{*}{$\begin{array}{c}\text { Разрез } \\
\text { (возраст залежи) }\end{array}$} & \multirow{2}{*}{ Почва } & \multirow{2}{*}{$\mathrm{C}_{\text {мпाг }} \%$ от $\mathrm{C}_{\text {общ. }}$} & \multicolumn{2}{|c|}{$\mathrm{C}_{\mathrm{nI}}$} & \multirow{2}{*}{$\mathrm{C}_{\mathrm{III}} / \mathrm{C}_{\mathrm{MII}}$} \\
\hline & & & $\%$ от $\mathrm{C}_{\text {общ. }}$ & мг/100 г почвы & \\
\hline $\begin{array}{c}\text { P. } 1 \\
\text { (35 лет) }\end{array}$ & $\begin{array}{l}\text { Темногумусовый } \\
\text { подбел глееватый }\end{array}$ & 68.4 & 31.6 & 1603.7 & 0.46 \\
\hline $\begin{array}{c}\text { Р. } 2 \\
(15 \text { лет) }\end{array}$ & Темногумусовый подбел & 70.3 & 29.7 & 559.5 & 0.42 \\
\hline $\begin{array}{c}\text { P. } 3 \\
\text { (15 лет) }\end{array}$ & То же & 70.3 & 29.7 & 597.0 & 0.42 \\
\hline $\begin{array}{c}\text { P. } 5 \\
\text { (20 лет) }\end{array}$ & $-"$ & 69.0 & 31.0 & 995.1 & 0.45 \\
\hline $\begin{array}{c}\text { P. } 6 \\
\text { (60 лет) }\end{array}$ & $\begin{array}{l}\text { Аллювиальная } \\
\text { серогумусовая }\end{array}$ & 67.6 & 32.4 & 949.3 & 0.48 \\
\hline $\begin{array}{c}\text { Р. } 7 \\
\text { (60 лет) }\end{array}$ & То же & 71.4 & 28.6 & 636.4 & 0.40 \\
\hline $\begin{array}{c}\text { Р. } 8 \\
(60 \text { лет) }\end{array}$ & $-"-$ & 73.9 & 26.1 & 756.9 & 0.35 \\
\hline
\end{tabular}

вышением в составе компонентов гумуса подвижных фракций гуминовых кислот. При этом поверхностным горизонтам данного типа почв свойственно и более высокое содержание гумуca (8.7\%). Из-за снижения доли углерода лабильного пула отмечено более узкое соотношение $\mathrm{C}_{\text {пг }}$ : $\mathrm{C}_{\text {мпг }}$ в темногумусовых подбелах по сравнению с темногумусовыми подбелами глееватыми.

В залежных аллювиальных серогумусовых почвах (р. 6, 8) зафиксировано возрастание углерода лабильного пула. Уровень ферментативной активности из-за активизации процессов трансформации органического вещества микрофлорой был достаточно высоким (см. рис. 2) и в основном соответствовал средней обогащенности почв каталазой (от 3.2 до $4.8 \mathrm{O}_{2} \mathrm{~cm}^{3} /$ Г почвы за 1 мин), что и явилось одной из причин более высоких показателей соотношения $\mathrm{C}_{\text {пг }}: \mathrm{C}_{\text {мпг }}$ Снижение доли лабильного пула в составе гумуса почв (р. 7) привело к уменьшению соотношения $\mathrm{C}_{\text {пг }}$ : $\mathrm{C}_{\text {мпг }}$ При этом обогащенность почв каталазой была «бедной» $\left(2.1 \mathrm{O}_{2} \mathrm{~cm}^{3} / \Gamma\right.$ почвы за 1 мин). Наибольшие потери лабильных компонентов установлены для залежных почв (р. 6) с высокими показателями каталазной активности $\left(4.8 \mathrm{O}_{2} \mathrm{~cm}^{3} / \Gamma\right.$ почвы за 1 мин). Однако от 67 до 73\% углерода содержалось в стабильном пуле, что указывало на сравнительно устойчивое гумусное состояние залежных почв.

\section{ВЫВОДЫ}

1. Нахождение почв в залежном состоянии привело к изменению их аккумулятивной толщи, что зафиксировано в общих морфологических признаках. В темногумусовых подбелах, находящихся в залежи более 20 лет, отмечено разделение исходного пахотного горизонта (0 20 см) на подгоризонты $(0-10,10-20,0-12,12-$ $20 \mathrm{~cm}$ ).

2. Исследуемые залежные темногумусовые подбелы, темногумусовые подбелы глееватые и аллювиальные серогумусовые почвы имели отличия в показателях гумусного состояния, а также лабильного и стабильного пулов углерода.

3. С увеличением времени нахождения темногумусовых подбелов в залежи (к 20 годам) отмечено увеличение содержания и запасов гумуса по сравнению с таковыми в пахотном аналоге.

4. В залежных аллювиальных серогумусовых почвах, судя по данным фракционно-группового состава, преобладала гуматная направленность в процессе гумусообразования, тогда как в темногумусовых подбелах она изменялась на гуматнофульватную. Исследуемым типам почв свойственна высокая степень гумификации органического вещества. В залежных почвах степень гумификации была несколько выше, чем в пахотных.

5. При нахождении почв в залежи отмечено сокращение доли гуминовых кислот, связанных с $\mathrm{Ca}^{2+}$, по сравнению с их долей в пахотных аналогах. Особенно ярко это проявлялось в темногумусовых подбелах глееватых и было связано не только с прекращением внесения удобрений, но и с их периодическим переувлажнением, вызванным усилением выпадения осадков во время тайфунов в 2017-2018 гг.

6. Происходящие изменения в содержании углерода стабильного и лабильного пулов свидетельствовали о различиях в процессах трансформации органического вещества изученных почв и подтверждались данными их ферментативной активности. Установлено, что основная доля 
углерода в исследуемых почвах содержалась в стабильном пуле. На увеличение доли углерода стабильного пула и переход гумуса в более устойчивое состояние указывало снижение соотношения между углеродом лабильного и стабильного пулов в почвах залежей.

Сбор образцов осуществлен при поддержке РНФ (проект № 17-76-10011).

\section{ЛИТЕРАТУРА}

Агрофизические методы исследования почв. М. : Наука, 1966. 256 с.

Витвицкий Г. Н. Климат. Природные условия и естественные ресурсы СССР. Южная часть Дальнего Востока. М. : Наука, 1969. С.70-96.

Государственная программа «Развитие сельского хозяйства и регулирования рынков сельскохозяйственной продукции, сырья и продовольствия. Повышение уровня жизни сельского населения Приморского края» на 2013-2020 годы от 07.12.2012 г. [Электрон. pecypc]. URL: http:// www.agrodv.ru/content/programmy-razvitiya-apk.

Зорина С. Ю., Соколова Л. Г., Засухина Т. В. Состояние гумуса агросерых почв лесостепи Прибайкалья в условиях техногенного загрязнения // Известия Самар. науч. центра РАН. 2014. Т. 16, № 5. С. 81-84.

Классификациия и диагностика почв России. М. : Изд-во Ойкумена, 2004. 341 с.

Ковалева Г. В., Щапова Л. Н., Пуртова Л. Н. Последействие десикантов на микрофлору и гумусное состояние почв Приморья в посевах озимой и яровой пшеницы // Вестник Бурят. гос. c/х академии им. В. Р. Филиппова. 2016. № 4 (45). С. 32-38.

Когут Б. М., Яиин М. А., Семенов В. М. и др. Распределение трансформированного органического вещества в структурных отдельностях дерново-подзолистой супесчаной почвы // Почвоведение. 2016. № 1. С. 52-56.

Костенков Н. М., Ознобихин В. И. Почвы и почвенные ресурсы юга Дальнего Востока и их оценка // Почвоведение. 2006. № 5. С. 517-526.

Ларионова А. А., Золотарева Б. Н., Евдокимов И. В. и др. Идентификация лабильного и устойчивого пулов органического вещества в агросерой почве // Почвоведение. 2011. № 6. С. 685-698.

Литвинович А. В., Павлова О. Ю. Изменение величины почвенной кислотности в процессе взаимодействия мелиорантов с почвами (по данным лабораторных и вегетационного опытов) // Агрохимия. 2010. № 10. C. 3-10.

Литвинович А. В., Павлова О. Ю. Изменение гумусного состояния дерново-подзолистой глееватой песчаной почвы на залежи // Почвоведение. 2007. № 11. С. 1323-1329.
Meтодbl почвенной микробиологии и биохимии / под ред. Д. Г. Звягинцева. М. : МГУ, 1991. 304 с.

Орлов Д. С., Бирюкова О. Н., Розанова М. С. Дополнительные показатели гумусного состояния почв и их генетических горизонтов // Почвоведение. 2004. № 8. С. 918-926.

Орлов Д. С., Гришина Л. А. Практикум по химии гумуса. М. : Изд-во МГУ, 1981. 376 с.

Платонычева Ю. Н., Полякова Н. В., Берчук А. В., Богомолова Ю. А. Влияние способов распашки залежи на подвижность органического вещества светлосерой лесной почвы // Аграрная наука Евро-СевероВостока. 2013. № 4 (35). С. 39-43.

Полякова Н. В., Платонычева Ю. Н., Нарчев М. $A$. Характер изменения органического вещества в серых лесных почвах залежи // Перспективы и проблемы размещения отходов производства и потребления в агроэкосистемах : материалы междунар. науч.практ. конф. / НГСХА. Н. Новгород : НИУ РАНХиГС, 2014. C. 174-178.

Пуртова Л .Н., Костенков Н. М., Щапова Л. Н. Оценка гумусного состояния и продуцирования $\mathrm{CO}_{2}$ почвами природных и агрогенных ландшафтов юга Дальнего Востока России // Почвоведение. 2017. № 1. С. 48-55.

Романовская А. А., Аракелян Т. Г. Почвенный органический углерод залежных земель в Московской области : Материалы IV Bcepoc. науч. конф. «Гуминовые вещества в биосфере», МГУ, Москва, 19-21 дек. 2007 г., СПб., 2007. С. 618-626.

Синельников Э. П. Оптимизация свойств и режимов периодически переувлажняемых почв : монография / ДВО ДОП РАН, Приморская ГСХА. Уссурийск, 2000. 296 c.

Хавкина Н. В. Гумусообразование и трансформация органического вещества в условиях переменноглеевого почвообразования : монография / ПГСХ. Уссурийск, 2004. 270 с.

Чалая T. А. Запасы углерода в почвах и растительности постагрогенных ландшафтов южной тайги : автореф. дис. ... канд. биол. наук. М., 2012. $26 \mathrm{c.}$

Kurganova, I., Lopes de Gerenyu, V., Six J., Kuzyakov, $Y$. Carbon cost of collective farming collapse in Russia // Glob. Change Biol. 2014. No. 20. P. 938947.

Poulton P. R., Pye E., Hargreaves P. R., Jenkinson $D$. S. Accumulation of carbon and nitrogen by old arable land reverting to woodland // Global Change Biol. 2003. Vol. 9. P. 942-955.

Wright A. L., Dou F., Hons F. M. Soil organic C and $\mathrm{N}$ distribution for wheat cropping systems after 20 years of conservation tillage in Central Texas // Agriculture, Ecosystems and Environment. 2007. No. 121. P. 376-382.

Zhang Bin, Penc XinHua. Organic matter enrichment and aggregate stabilization in a severely degraded ultisol after reforestation // Pedosphere. 2006. No. 16 (6). P. 699-706. 


\title{
HUMUS CONDITION IN SOME FALLOW SOIL TYPES IN PRIMORYE
}

\author{
L. N. Purtova, I. V. Kiseleva, M. L. Burdukovsky
}

\author{
Federal Scientific Center of Biodiversity in East Asia's Terrestrial Biota, FEB RAS, Vladivostok
}

The parameters of the humus status of fallow dark-humus bleached horizons and alluvial gray-humus soils in Primorye have been estimated. In fallow alluvial gray-humus soils, the humate orientation prevailed in the process of humus formation, whereas in dark humus soils, it was changed to humate-fulvate. Characteristic for the studied soil types is a high degree of organic matter humification. When in a fallow soils are marked with a decrease in the proportion of humic acids associated with $\mathrm{Ca}^{2+}$, in comparison with their arable counterparts. The pools of labile and stable carbon are calculated. The main share of carbon (from 67 to $73 \%$ ) in the investigated soils is contained in a stable pool. An increase in the carbon fraction of the stable pool and the transition of humus to a more stable state, in the investigated soils of the deposits, was indicated by a decrease in the ratio between the carbon of the labile and stable pools.

Keywords: soils, reservoir, humus status, carbon pools, catalase activity.

\section{REFERENCES}

Agrophysical Methods of Soil Investigation, 1966, Moscow, Nauka [In Russian].

Chalaya, T. A., 2012, Carbon Stocks in Soils and Vegetation of the Postagrogenic Landscapes of the Southern Taiga, Avtoref. Diss. Cand. Bio. Sci., Moscow, Moscow State University [In Russian].

Classification and Diagnostics of Russia's Soils, 2004, Moscow, Oykumena [In Russian].

Government Program "Development of Agriculture and Regulation of Markets for Agricultural Products, Raw Materials and Foodstuffs. Improving the Living Standards of Rural Population of Primorsky Kray for 2013-2020 of 07.12.2012, http://www.agrodv.ru/content/programmyrazvitiya-apk [In Russian].

Khavkina, N. V., 2004, Humus Formation and Organic Matter Transformation in Conditions of Variable Gley Soil Formation: Monograph, PGSH, Ussuriysk [In Russian].

Kogut, B. M.; Yashin, M. A.; Semenov, V. M.; Avdeeva, T. N.; Markina, L. N.; Lykin, S. M.; Tarasova, S. I., 2016, Distribution of Transformed Organic Matter in Structural Units Loamy Sandy Soddy-Podzolic Soil, Eurasian Soil Science, 46, 1, 45-55, DOI: 10.1134/ S1064229316010075

Kostenkov, N. M.; Oznobikhin, V. I., 2006, Soils and Soil Resources in the Southern Far East and Their Assessment, Ibid., 39, 5, 461-469, DOI: 10.1134/ S1064229306050012

Kovaleva, G. V.; Shchapova, L. N.; Purtova, L. N., 2016, The After-Effect of Desiccants on the Microflora and Humus Condition of the Soils of Primorye in Winter and Spring Wheat Seeding, Bulletin of Buryat State Academy of Agriculture, 4 (45), 32-38 [In Russian].

Kurganova, I.; Lopes de Gerenyu, V.; Six J., Kuzyakov, Y., 2014, Carbon Cost of Collective Farming Collapse in Russia, Glob. Change Biol., 20, 938-947.

Larionova, A. A.; Zolotareva, B. N.; Evdokimov, I. V.; Bykhovets S. S.; Kuzyakov, Y. V.; Burger, F., 2011, Identification of Labile and Stable Pools of Organic Matter in Agrogray Soil, Eurasian Soil Science, 6, 685-698.
Litvinovich, A. V.; Pavlova, O. Yu., 2007, Change in the Humus Status of Sandy Gleyic Soddy-Podzolic Soil on a Fallow, Eurasian Soil Science, 40, 11, 1181-1186.

Litvinovich, A. V.; Pavlova, O. Yu., 2010, The Change in Soil Acidity in the Process of Interaction of Ameliorants with Soils (According to Laboratory and Vegetation Experiments), Agrochemistry, 10, 3-10 [In Russian].

Methods of Soil Microbiology and Biochemistry, 1991, Ed. D. G. Zvyagintsev, Moscow, Moscow State University [In Russian].

Orlov, D. S.; Biryukova, O. N.; Rozanova, M. S., 2004, Additional Parameters of the Humus Status of Soils and Their Genetic Horizons, Eurasian Soil Science, 37, 8, 798-805.

Orlov, D. S.; Grishina, L. A., 1981, Practice in Humus Chemistry, Moscow, Moscow State University [In Russian].

Platonycheva, Yu. N.; Polyakova, N. V.; Berchuk, A. V.; Bogomolova, Yu. A., 2013, Influence of the Fallow Plowing Methods on Mobility of the Organic Matter of the Light Gray Forest Soil, Agrarian Science of the EuroNorth-East, 4, 35, 39-43 [In Russian].

Polyakova, N. V.; Platonycheva, Yu. N.; Narchev, M. A., 2014, Nature of the Organic Matter Change in Gray Forest Soils of Fallows, Prospects and Problems of Locating Production and Consumption Wastes in Agroecosystems, Materials of Scientific-Practical. Conf., Nizhegorodskaya Gosselkhozakademiya, N. Novgorod, NNIM RANEPA, 174-178 [In Russian].

Poulton, P. R.; Pye, E.; Hargreaves P. R.; Jenkinson D. S., 2003, Accumulation of Carbon and Nitrogen by Old Arable Land Reverting to Woodland, Global Change Biol., 9, 942-955.

Purtova, L. N.; Kostenkov, N. M.; Shchapova, L. N., 2017, Assessing the Humus Status and $\mathrm{CO}_{2}$ Production in Soils of Antropogenic and Agrogenic Landscapes in Southern Regions of the Russian Far East, Eurasian Soil Science, 50, 1, 48-55 [In Russian].

Romanovskaya, A. A.; Arakelyan, T. G., 2007, Soil Organic Carbon of Fallow Lands in Moscow Oblast, Humic 
Substances in the Biosphere, Materials of the IV AllRussia Science Conference, Moscow State University, Moscow, December 19-21, 2007, St. Petersburg, 618626 [In Russian].

Sinelnikov, E. P., 2000, Optimization of Properties and Regimes of Periodically Overmoistened Soils, Monograph, Primorskaya State Academy of Agriculture, Ussuriysk [In Russian].

Vitvicki, G. N., 1969, Climate. Natural Conditions and Natural Resources of the USSR. Southern Part of the Far East, Moscow, Nauka, 70-96 [In Russian].

Wright, A. L.; Dou, F.; Hons, F. M., 2007, Soil Organic $\mathrm{C}$ and $\mathrm{N}$ Distribution for Wheat Cropping Systems after 20 Years of Conservation Tillage in Central Texas, Agriculture, Ecosystems and Environment, 121, 376382.

Zhang, Bin; Penc, XinHua, 2006, Organic Matter Enrichment and Aggregate Stabilization in a Severely Degraded Ultisol after Reforestation, Pedosphere, 16 (6), 699-706.

Zorina, S. Yu.; Sokolova, L. G.;Zasukhina, T. V., 2014, The Humus Status in the Agrogray Soils of the Baikal Forest-Steppe in Technogenic Contamination, Izvestia of Samara Scientific Center of the Russian Academy of Sciences, 16, 5, 81-84 [In Russian]. 